\title{
Abundance and Diversity of Woody Undergrowth Reservoir as Indicator of Suitable Vegetation Patch for Natural Regeneration
}

\author{
Saran Traoré1,2,3* (D) Issiaka Keïta ${ }^{1,2}$, Sébastien Ange Habih Nombré1,2, \\ Hassan Bismarck Nacro², Brice Sinsin ${ }^{4}$ \\ ${ }^{1}$ UFR/de la Vie et de la Terre, Université Nazi Boni, Bobo-Dioulasso, Burkina Faso \\ ${ }^{2}$ Laboratoire d'Etude et de Recherche en Fertilité de Sols, IDR, Université Nazi Boni, Bobo-Dioulasso, Burkina Faso \\ ${ }^{3}$ Laboratoire de Biologie et Ecologie Végétales, UFR-Sciences de la Vie et de la Terre, Université Joseph Ki-Zerbo, Ouagadougou, \\ Burkina Faso \\ ${ }^{4}$ Laboratoire d'Ecologie Appliquée, Faculté des Sciences Agronomiques, Université d'Abomey-Calavi, Cotonou, \\ République du Bénin \\ Email: *sarantraore_2003@yahoo.fr, *saran.traore@univ-bobo.bf
}

How to cite this paper: Traoré, S., Keïta, I., Nombré, S.A.H., Nacro, H.B. and Sinsin, B. (2022) Abundance and Diversity of Woody Undergrowth Reservoir as Indicator of Suitable Vegetation Patch for Natural Regeneration. Open Journal of Ecology, 12, 113-132.

https://doi.org/10.4236/oje.2022.122007

Received: December 19, 2021

Accepted: January 27, 2022

Published: January 30, 2022

Copyright $\odot 2022$ by author(s) and Scientific Research Publishing Inc. This work is licensed under the Creative Commons Attribution International License (CC BY 4.0).

http://creativecommons.org/licenses/by/4.0/

\section{(c) (i) Open Access}

\begin{abstract}
The diversity, abundance and height structure of naturally regenerated woody species were analyzed and compared for undergrowth reservoir associated with vegetation patches as bowal, shrubland and woodland for understanding the effect of vegetation conditions on spatial distribution of woody plants in Sudanian ecosystem. All undergrowth individuals (height $<1.5 \mathrm{~m}$ ) were recorded by species and the total height and collar diameter were measured in 50 subplots of $5 \mathrm{~m} \times 5 \mathrm{~m}$ (or $25 \mathrm{~m}^{2}$ ) laid out in each vegetation patch during rainy season. In total 52 undergrowth species and 2224 stems arranged in 38 genera and 21 families out of which 25, 36 and 38 species were found in bowal, shrubland and woodland respectively and 15 shared species. Combretaceae, Caesalpiniaceae and Mimosaceae families were the most abundant and species density was significantly higher $(\mathrm{P}<0.05)$ in shrubland and woodland than bowal, and increase diversity in only shrubland $(\mathrm{P}=0.002)$ comparing with bowal. Undergrowth was abundantly concentrated in small height class as canopy benefit and indicate a specific-site distribution. Results also showed that bowal had a particular vegetation which vary in function of tree community characters in place $(\mathrm{P}<0.05)$ while woodland and shrubland are similar vegetation patches. As conclusion, the study vegetation patches form suitable regeneration niches for the undergrowth reservoir of limited number of species which in return can be predictor of species richness and abundance and thus the structure of tree community. Woody undergrowth community could be considered in biodiversity management and degraded land restoration.
\end{abstract}


Supplementary works could be undertaken to understand the characteristics of seed bank for bowal, shrubland and woodland regarding the undergrowth and tree communities.

\section{Keywords}

Biodiversity Conservation, Burkina Faso, Regeneration, Spatial Heterogeneity, Sudanian Ecosystems

\section{Introduction}

Restoring woody community for conservation goal with its species diversity basednaturally occurrence in savanna and woodland ecosystems in arid and semi-arid regions have always been of broad concerns for vegetation management by plant ecologists, biologists, evolutionists and environmentalists. One reason is the fluctuation observed in woody species composition and diversity, discontinuous structure and pattern of woody stratum within or between landscape which reflect the magnitude and instability of species establishment and recruitment [1] [2]. Although many efforts have been conceded and are increasingly underway [3] [4] [5] [6] to overcome these concerns, the mechanisms or way in which plant species colonize or regenerate and recruit in a given area and vegetation condition vary largely in the literature [7] [8] [9] [10] [11]. It is reported in West Africa, in Sudano-Sahelian ecosystems that many woody species asexually regenerate naturally in the landscapes of Daniellia oliveri, Detarium microcarpum or Isoberlinia doka [9] while species as Crossopteryx febrifuga is able to recruit and resist in a wider range of fire conditions than Piliostigma sp [8]. According to Do et al. [12] undergrowth species decline in disturbed vegetation. These authors have recorded 54 woody species in high human impacted forest, 66 in low impacted and 56 in intact forest at seedling stage against 55, 73 and 77 at sapling stage and 90, 102 and 98 at tree stage respectively and significant increase in sapling density for high impacted forest and similar distribution in seedling density.

Obviously, in many arid and semi-arid regions, the natural vegetation is the main source that supplies with natural resources and environment benefits for local resident well-being [11] [13] [14]. Several species are overharvested for household needs and others are ecologically used for land protection. The recurrent tree pruning of many species maintain these trees in juvenile stage while the loss of many natural habitats generated by the constant change or transformation of arable lands for agriculture extension and/or urbanization purposes lead to modify the vegetation structure and conditions [15] [16] and thereafter hind their natural regeneration by suppressing seed production. These factors also act to reduce the size of plant population. Whenever the conditions of vegetation shape the woody tree strata [17], the dynamic and quality of the natural undergrowth successfully established and recruited remains the main responsible of the future composition and structure in particular woody community. It is suggested that 
the undergrowth ability to escape disturbance effects and changing environment and therewith their performance to grow can be very considerable [7]. Therefore, the characteristics of natural woody vegetation widely varied from site to site in the same landscape as the clue of limited establishment and recruitment in woody community. Subsequently, some species that escape changing environment manage to reproduce abundantly, persist and recruit in the conditions of the new habitat and the others either decline or perish and hereafter jeopardize the stability of local biodiversity inside the same phytogeographical edge. During their investigations Attua et al. [15] have observed among study zones, the preponderance of the species of Fabaceae family in both least and medium human activities while the species of Fabaceae, Malvaceae and Moraceae families were most represented under higher activities.

In Sudanian Africa, strong soil compaction and moisture deficit are also factors that lead natural population regression in savanna. Therefore, quantifying the regeneration status of woody species in these ecosystems become indisputable subject to understand the distribution and assemblage of species in a given area despites the effects of ecological interactions [4]. Previous research have highlighted that the success or fail of species to establish is guided by the probability and quality of undergrowth to establish while its recruitment is influenced by habitat type or microsite characteristics and/or their interactions [10] [18]. When scarce woody vegetation may be benefit for savanna native species dense vegetation patch as woodland may facilitate shade tolerant and/or forest native undergrowth species to establish [19] [12] [20] [21]. For [19] the undergrowth number of Vitellaria paradoxa was significantly higher under the tree crowns of Parkia biglobosa and V. paradoxa than outside crown cover. According to [21] seedling density was higher Eucalyptus camaldulensis plantation forest (2567 stems/ha) in comparison with the native woodland (2267 stems/ha) almost similar whereas unprotected site better promote seedling emergence with the highest density than in protected one across phytogeographical regions [22]. Comparatively few or no attention has been addressed at understanding the characteristics of the woody undergrowth reservoir along vegetation patches as shrubland and woodland in the same landscape. Therefore, current investigation was undertaken to assess the regeneration potential of woody species in secondary disturbed ecosystems that could be candidate for conservation and/or restoration for particular woody species populations, or might be equivalent to the same area at different times. The aim of this study was to characterize the community of woody undergrowth and the relationship between undergrowth and trees of the same species across vegetation patches as habitats or regeneration niches. We specifically assessed firstly, 1) the species composition and diversity of undergrowth; 2) the density and structure of undergrowth stem; 3) whether the species richness and stem density of undergrowth community vary in function of those of tree community within area and secondly, 4) the regeneration status of the most shared species within area relating to the conspecific tree community to find out the preferred regeneration niche. As research question 
"How important is undergrowth community in secondary disturbed vegetation patch?”

\section{Material and Methods}

\subsection{Study Site Description}

The field work was carried out in a sub-urban forest in West part of Burkina Faso at an altitude of $300 \mathrm{~m}$ a.s.l. This sub-urban forest is located in the northwest of Bobo-Dioulasso the second main city of the country $\left(11^{\circ} \mathrm{N}-12^{\circ} \mathrm{N}\right.$ and $\left.4^{\circ} 10^{\prime} \mathrm{W}-4^{\circ} 30^{\prime} \mathrm{W}\right)$. The local climate is characterized by the alternance of a dry and a rainy season. Data recorded by local meteorology department from 1999 to 2019 showed that the rain season lasts from April to October (7 months) with an average rainfall of $1038.68 \pm 174.31 \mathrm{~mm}$ per annum while a total rainfall of $1320 \mathrm{~mm}$ and $1349.8 \mathrm{~mm}$ were recorded in 2018 and 2019 respectively. The dry season lasts from November to March (4 months). January is the coldest month with $15.89^{\circ} \mathrm{C}$ and April the hottest with $40.42^{\circ} \mathrm{C}$.

Soils based on sedimentary rocks are considered as Lixisols according to the FAO classification system [23]. These soils are slightly deep $(>85 \mathrm{~cm})$ and dominated by a loamy-sandy texture (57.5\%) with the presence of sandy structures (17.5\%), sandy loamy (15\%) and other structures (10\%) (BUNASOLs, 1985) in [24].

The local vegetation is savannah of South-Sudanian domain included in the Sudanian regional centre of endemism [25]. This vegetation is a mosaic patch constituted of opened tree and bush savannah, wooded and opened woodlands [26] with annual and/or perennial grasses and bare lands.

\subsection{Study Plant Community}

We considered vegetation patches on bowal outcrop (opened canopy), shrubland (semi-opened) and woodland (closed canopy). This is because the vegetation patches or canopy conditions can modify the regeneration degree through the distribution, floristic composition, diversity and structure of naturally occurred woody undergrowth reservoir. According to [27], woodland is defined by the abundance of individuals of species Anogeissus leiocarpus (DC.) Guill. \& Perr., Combretum spp, Detarium microcarpum Guill. \& Perr., Isoberlinia doka Craib \& Stapf., Pterocarpus erinaceus Pair., Terminalia spp and Vitellaria paradoxa var. paradoxa Gaertn $\mathrm{f}$. The mean density was $497.00 \pm 180.62$ stems $\cdot \mathrm{ha}^{-1}$ and height $5.43 \pm 0.73 \mathrm{~m}$. Shrubland shelter Acacia macrostachya Reichenb. ex DC, Combretum spp, Lannea spp, Gardenia spp, Maranthes polyandra (Benth.) Prance, Crossopteryx febrifuga (Afzel. ex G. Don) Benth, Sarcostemma viminale (L.) R.Br with a total height not over $2 \mathrm{~m}$ above soil surface and annual grass layer as Loudetia togoensis (Pilg.) C. E. Hubb., and Pennisetum pedicellatum. The shrubland is dominated by woody shrub species with an opened layer (stem density $620.00 \pm 175.94$ stems.ha ${ }^{-1}$ and mean height $5.24 \pm 0.40 \mathrm{~m}$ ) and annual grass layer, with occasional tree saplings. Bowal (plural: bowé) also refers to a shrubland but corresponds to an "edaphico-climatic" grassy formations of the 
semi-desert plateaus fossilized by an outcropping or sub-outcropping breastplates, and with hydromorphic silts [28]. Soil surface is interrupted by crusted soils and mushroom-shaped mounds erected by Cubitermes spp (humivorous) at $99 \mathrm{ha}^{-1}$ [29]. Annual grass as Loudetia togoensis was recurrent with some scattered shrub species during rainy season on bowal. The average density was $436.00 \pm 235.10$ stems $\cdot \mathrm{ha}^{-1}$ and height, $4.52 \pm 0.78 \mathrm{~m}$. These few scattered shrubs disappear during the dry season leaving to discover a bare soil.

\subsection{Experimental Design and Undergrowth Inventory}

We firstly delimited 30 contiguous plots of $50 \mathrm{~m} \times 20 \mathrm{~m}$ [30] randomly in the state forest of Dinderesso following transect lines that included the direction of the rainwater flow. All tree species which stem dbh was equal to or greater than $5 \mathrm{~cm}$ were systematically recorded and measured in the 30 plots (or $3 \mathrm{ha}$ ) or tree-plots as adult community. We identified 58 species belonging to 42 families and 18 genera, with Combretaceae (168 trees $\cdot \mathrm{ha}^{-1}$ ), Fabaceae (111.67 trees $\cdot \mathrm{ha}^{-1}$ ), Sapotaceae $\left(64.67\right.$ trees $\left.\cdot \mathrm{ha}^{-1}\right)$, Caesalpiniaceae $\left(63\right.$ trees $\cdot \mathrm{ha}^{-1}$ ) the most abundant families in terms of tree density [31]. The density and height of trees in at plot scale was affected by the type of vegetation assemblage.

In each major plot, 50 subplots of $5 \mathrm{~m} \times 5 \mathrm{~m}\left(\right.$ or $\left.25 \mathrm{~m}^{2}\right)$ were established on bowal, shrubland and woodland. Among these subplots, 5 were laid with one subplot at the centre and one subplot at each of the 4 corners (diagonally arranged) for collecting undergrowth data in tree-plots. In total, 150 subplots were established and considered.

Data on undergrowth plant communities were collected in the rainy season during which all the woody species as seedlings, saplings and trees are leafy and identifiable. This period also corresponded to that of the abundant emergence of the undergrowth of many species either by seed germination or resprouting of the remaining stem or sucker [10]. Inventory was proceeded from August to November 2018. Undergrowth species were identified using vegetation community characteristics and botanical criteria of [27] and by comparing morphologically with trees of the same species. The sample of undetermined species were taken to be later identified at laboratory with referring to available data on African woody species. Scientific name were cross-checked according to [32] and [33]. For all live individual of which the diameter at breast height (dbh) less than $5 \mathrm{~cm}$ and total height of stem equal to or less than and $150 \mathrm{~cm}$ were systematically counted as woody undergrowth contrary to adult tree (mature). The total height of undergrowth individual was measured using a graduated perch of $7 \mathrm{~m}$, at each $50 \mathrm{~cm}$ and their collar diameter was measured with calliper $(0.01 \mathrm{~mm}$ precision). Only the tallest stem was considered in case of more than stem for individuals.

\subsection{Undergrowth Data Analysis}

We used the number of $25 \mathrm{~m}^{2}$ subplots in which undergrowth species occurred 
in each tree-plot $\left(1000 \mathrm{~m}^{2}\right)$. We firstly explored the data on undergrowth plant community alone to assess species richness (S) and floristic composition. Species richness was determined based on the number of species identified (S) and as species density which refers to the number of species identified in the total area of each subplot [34]. Species density is thus expressed as the number of species (S) at $100 \mathrm{~m}^{2}$ of area. Species name were written in full for the first time and, generic name was used thereafter. When more than one species were identified in the same genus, the generic name was abbreviated and followed by specific epithet.

The species diversity of undergrowth was calculated and the Simpson's index of diversity $I$ (Equation (1)) [35] was calculated for each subplot of $5 \mathrm{~m} \times 5 \mathrm{~m}$ to evaluate the species diversity as the probability that two random individuals belong to the same habitat:

$$
I=1-D=1-\frac{\sum_{i=1}^{i=s} n i(n i-1)}{N(N-1)}
$$

where $N$ is the total number of woody undergrowth recorded, $s$ the number of species and $n i$ the total number of individuals of species $i$. The Simpson's index of diversity $(I)$ consider the number of species present in a community and the abundance of each species as single statistic. Its values range from 0 (low diversity) to 1 (high diversity).

For assessing the height distribution in undergrowth community, all the recorded individuals growing on bowal, shrubland and woodland were separated into six different height classes as ]0 - 25], ]25 - 50], ]50 - 75], ]75 - 100], ]100 125], ]125 - 150] with their corresponding density in each community.

We noted species richness and abundance as total number of species and stem per unit of area or density. Since the size of sampled areas for undergrowth and tree communities were different, both species richness and abundance were balanced by the sampled plots (trees) or subplots (undergrowth) and then standardized per $100 \mathrm{~m}^{2}$ of area. This method also has been used by [10] for facilitating the comparison of species between various areas.

The mean values of 1) species density, 2) Simpson's index of diversity, 3) the mean density and collar diameter of undergrowth stem were calculated for each vegetation patch and compare to find out the regeneration niche preferences of woody species. The variation of undergrowth stem density among habitats or vegetation patches was analyzed using the one-factor ANOVA of Minitab 15 and then the test of multiple comparisons of mean values were performed when the observed differences were significant at probability $\mathrm{P}=0.05$ based on Tukey's (HSD) test. In addition, the test of linear regression was used to highlight the relationships that could exist between undergrowth and tree communities in each habitat regarding their characteristics. These analysis involved both species richness and stem density to evaluate which of bowal, shrubland and wood shows good undergrowth reservoir as suitable niche of natural regeneration. 


\section{Results}

\subsection{Effects of Vegetation Patch on Alpha Diversity of Undergrowth}

We recorded overall 52 undergrowth species and 2224 stems that belonged to 38 genera and 21 families along the study period. Among these species, 25, 36 and 38 species were identified in bowal, shrubland and woodland respectively (Appendix). The families of Combretaceae (6 species), Caesalpiniaceae ( 4 species), and Mimosaceae (3 species) were largely represented in bowal while Combretaceae ( 9 species), Caesalpiniaceae (6 species), Euphorbiaceae (3 species), Rubiaceae ( 3 species) dominated in shrubland. The families of Combretaceae (7 species), Caesalpiniaceae (6 species), Rubiaceae (4 species), Euphorbiaceae ( 3 species) and Mimosaceae (3 species) prevailed in woodland.

All the three vegetation patches shared 15 species with each other while 3 species were common in bowal and woodland, and 13 species were found in both shrubland and woodland (Appendix). Only 1 species as Opilia celtidiflora Endl. S. Walp. was found in both bowal and shrubland. In fact, 6 species were solely identified in bowal, and 7 species in each of shrubland and woodland respectively. The occurrence of species $O$. celtidiflora in bowal seems to be accidentally and linked to fruit (or seed) dispersal process.

The calculated values of species richness as species density at $100 \mathrm{~m}^{2}$ unit of area and Simpson's index of diversity I of undergrowth community were lower for bowal, higher for shrubland, and intermediate for woodland (Table 1). Statistically, vegetation patching significantly influenced the species density (Anova, $\mathrm{F}=38.08, \mathrm{P}<0.0001$ ) and Simpson's index of diversity $\mathrm{I}$ (Anova, $\mathrm{F}=7.15, \mathrm{P}=$ 0.003). Importantly, the pairwise comparison of mean value revealed that species density was strongly increased for shrubland $(\mathrm{P}<0.0001)$ and woodland $(\mathrm{P}<$ $0.0001)$ in comparison with bowal while it did not differ significantly between shrubland and woodland $(\mathrm{P}=0.618)$, and between woodland and bowal $(\mathrm{P}=$ 0.078) (Table 1). In contrast, the difference observed in the Simpson's index of diversity was only significant for shrubland $(\mathrm{P}=0.002)$ comparing with bowal whereas it was insignificant between shrubland and woodland $(\mathrm{P}=0.311)$ and, between woodland and bowal $(\mathrm{P}=0.078)$. The test of Tukey discriminated two homogeneous groups ( $\mathrm{a}$ et $\mathrm{b}$ ) relating to specific density and stem density (Table 1): bowal (a) is species-poor site and shrubland-woodland together form a richspecies site (b). In return, undergrowth community in bowal (a) was less diversified and shrubland (b) more diversified vegetation regarding the undergrowth characteristics.

\subsection{Effects of Vegetation Patch on the Structure of Undergrowth}

Undergrowth individuals were counted in $50 \times 25 \mathrm{~m}^{2}$ (or $125 \mathrm{~m}^{2}$ ) per vegetation patch. The overall density of undergrowth ranged from $35.28 \pm 19.11$ stems 100 $\mathrm{m}^{-2}$ (or 441 individuals $125 \mathrm{~m}^{-2}$ ) on bowal to $76.88 \pm 21.02$ stems $\cdot 100 \mathrm{~m}^{-2}$ (961 individuals. $125 \mathrm{~m}^{-2}$ ) in woodland. This density was lower for bowal and intermediate for shrubland (Table 1). The most abundant families were Combretaceae, 
Table 1. Species density, Simpson's index of diversity and abundance of woody undergrowth at subplot-level on bowal, shrubland and woodland in the study site (mean \pm standard deviation).

\begin{tabular}{|c|c|c|c|c|c|}
\hline \multirow{2}{*}{ Variables } & \multicolumn{3}{|c|}{ Subplot location } & \multirow[b]{2}{*}{$\mathbf{F}$} & \multirow[b]{2}{*}{ P. } \\
\hline & Bowal & Shrubland & Woodland & & \\
\hline Subplot no. & 50 & 50 & 50 & & \\
\hline \multicolumn{6}{|l|}{ Species diversity of undersgrowth } \\
\hline Number of observed genus & 23 & 28 & 33 & & \\
\hline Number of observed family & 13 & 18 & 19 & & \\
\hline Number of observed species & 25 & 36 & 38 & & \\
\hline Species density (no. species $100 \mathrm{~m}^{-2}$ ) & $4.72 \pm 2.83^{\mathrm{a}}$ & $13.52 \pm 1.83^{\mathrm{b}}$ & $12.48 \pm 2.62^{\mathrm{b}}$ & 38.08 & $<0.0001$ \\
\hline Simpson's index of diversity I (1-D) & $0.63 \pm 0.24^{\mathrm{a}}$ & $0.88 \pm 0.03^{b}$ & $0.78 \pm 0.08^{\mathrm{ab}}$ & 7.15 & 0.003 \\
\hline \multicolumn{6}{|l|}{ Undergrowth abundance } \\
\hline Number of observed stems & 441 & 822 & 961 & & \\
\hline Mean stem density (no. stems $100 \mathrm{~m}^{-2}$ ) & $35.28 \pm 19.11^{\mathrm{a}}$ & $65.76 \pm 11.82^{\mathrm{b}}$ & $76.88 \pm 21.02^{\mathrm{b}}$ & 14.7 & $<0.001$ \\
\hline Mean stem collar diameter $(\mathrm{cm})$ & $1.21 \pm 0.77^{\mathrm{a}}$ & $1.18 \pm 0.91^{\mathrm{a}}$ & $1.07 \pm 0.83^{\mathrm{b}}$ & 5.55 & 0.004 \\
\hline Minimum diameter $(\mathrm{cm})$ & 0.10 & 0.10 & 0.10 & & \\
\hline Maximum diameter $(\mathrm{cm})$ & 6.70 & 7.50 & 10.00 & & \\
\hline
\end{tabular}

Mean values with different letter(s) across the same line for each vegetation type are significantly different (at $\mathrm{P}<0.05)$ according to Tukey's HSD test.

Mimosaceae, Caesalpiniaceae, Sapotaceae and Euphorbiaceae (Appendix) with abundant individuals.

At the scale of vegetation patches, the families of Caesalpiniaceae and Combretaceae were prevalent in bowal whereas Combretaceae, Mimosaceae were substantially represented in shrubland and woodland respectively.

Out of the shared species, Detarium microcarpum Guill. \& Perr., Guiera senegalensis Lam. and Diospyros mespiliformis Hochst. ex A. DC. were abundantly represented in bowal. Depending on site characteristics, species as G. senegalensis, Dichrostachys cinerea (L.) Wight \& Arn. and Vitellaria paradoxa var. paradoxa C.F. Gaertn were the most abundant species in shrubland whereas the undergrowth of $D$. cinerea, $G$. senegalensis and $V$. paradoxa dominated in woodland.

When we calculated the value of the ratio of shared undergrowth species over tree communities among patch, we noticed a preponderance of undergrowth individuals compared with adult tree within species (Appendix). There was much more undergrowth than adult trees as limited regeneration of these species. Undergrowth density was significantly different across vegetation type (Anova, $\mathrm{F}=$ 14.7, $\mathrm{P}<0.001$ in Table 1$)$. According to Tukey's test the mean density of undergrowth was higher for shrubland $(\mathrm{P}=0.002)$ and woodland $(\mathrm{P}<0.0001)$ than bowal but this observed difference between shrubland and woodland was not significant $(\mathrm{P}=0.355)$. Regarding the abundance distribution of undergrowth 
individuals, bowal (a) refers to a particular vegetation set and pool community of shrubland-woodland (b) form the other homogeneous vegetation.

The collar diameter of undergrowth varied from $1.07 \pm 0.83 \mathrm{~cm}$ in woodland to $1.21 \pm 0.77 \mathrm{~cm}$ in bowal as the highest value (Table 1 ). The minimum collar diameter recorded in each area was the same while the maximum ranged from $6.70 \mathrm{~cm}$ in bowal to $10 \mathrm{~cm}$ in woodland indicating the development level of their underground systems.

The mean values of stem collar diameter remarkably varied from one site to another (Anova, $\mathrm{F}=5.55, \mathrm{P}=0.004$ ). Difference observed in these mean values was strongly higher for bowal $(P=0.006)$ and shrubland $(P=0.032)$ compared with woodland while it was not significant between bowal and shrubland $(\mathrm{P}=$ 0.849 ) showing similar community (Table 1 ). The multiple comparison of mean values indicated two homogeneous groups as bowal-shrubland (a) and woodland (b) in term of stem collar diameter.

\subsection{Effects of Vegetation Patch on Height Class Distribution}

The abundance distribution of undergrowth varied according to the height classes (Figure 1). This distribution was in bell-shaped and represented a gauss-type structure reflecting poor regeneration and recruitment on bowal regarding the tendency curve shape (Figure 1(a)). Most individuals in this community or 92\% occurred as aggregated in the midst height classes between 50 and $100 \mathrm{~cm}$ tall. In contrast, the tendency curve showed that the distribution of undergrowth stems was in reverse $J$ shape for the shrubland and woodland communities (Figure 1 (b) and Figure 1(c)). There was a decrease in undergrowth abundance from $] 25$ - 50], ]50 - 75], ]75 - 100], ]100 - 125] to ]125 - 150] in shrubland and woodland towards higher height class. The incidence of undergrowth individuals in height class ]0 - 25] and those with height $>100$ were scarce. Such distribution seems to be linked to canopy degree and indicate distribution as specific-site (bowal) vs. similar homogeneous distribution model in both shrubland and woodland communities.

\subsection{Relationship between Undergrowth and Tree Communities}

The linear regression analyses were performed to explore the relationship between tree community as explanatory variable and undergrowth community as response variable (specie and stem densities). The expected results highlighted positive relationship between undergrowth and tree communities (Anova, $\mathrm{P}<$ $0.05)$ in bowal while it was statistically good between undergrowth and tree stem densities only in woodland (Anova, $\mathrm{P}<0.05$ ) (Table 2). The observed species richness of undergrowth was 53\% explained by that of tree species and their stem densities at $42 \%$ by that of tree density for bowal. In shrubland, undergrowth and tree communities were almost independent $(P>0.05)$ with weak relationship between them. Only few variations of undergrowth species richness (26.50\%) and stem density (16.20\%) was explained respectively by species richness 

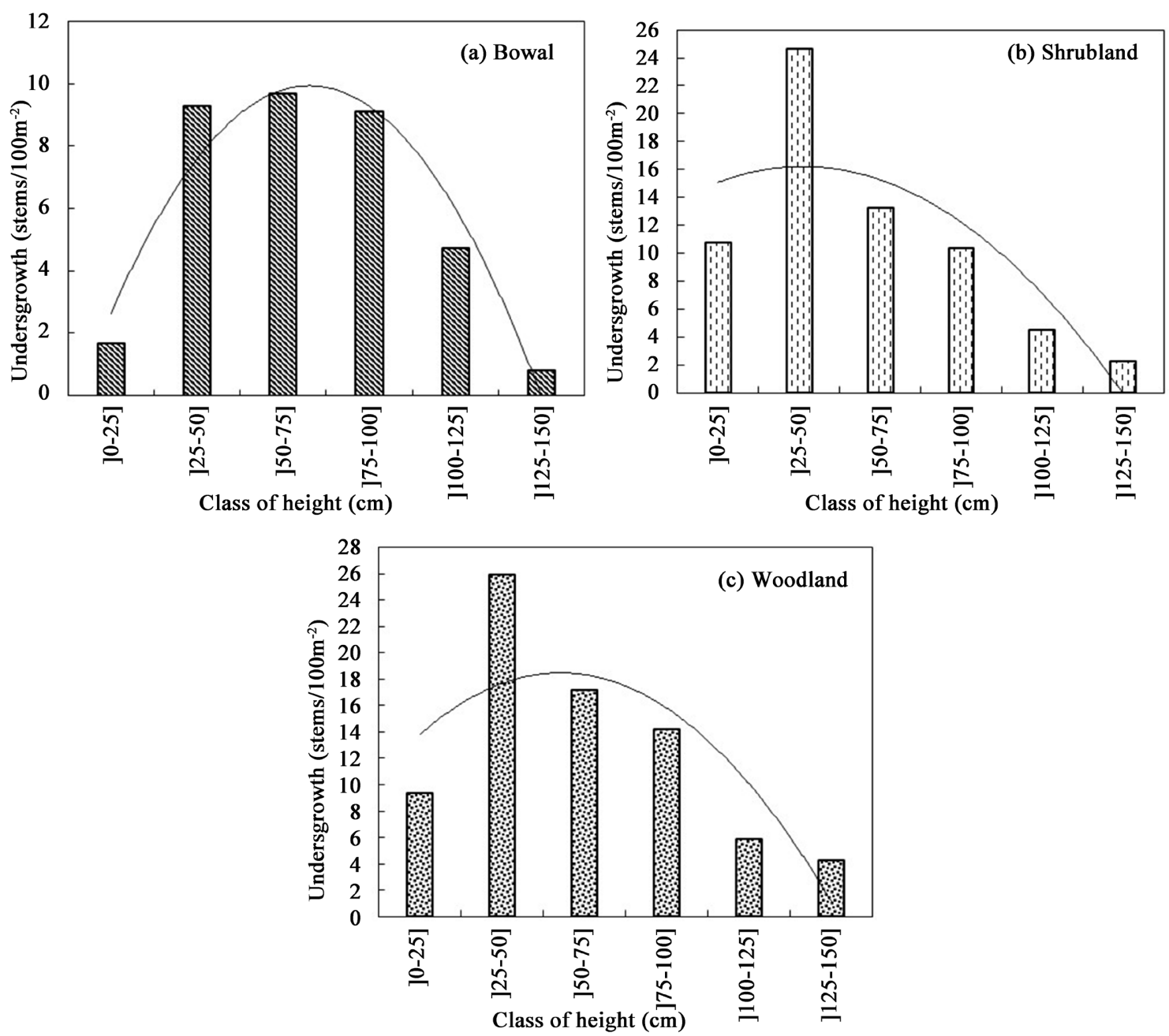

Figure 1. Pattern of the height class pattern of woody undergrowth recorded in 2018 in bowal (a), shrubland (b) and woodland $(c)$.

Table 2. Linear relationship between the species richness and stem density of woody undergrowth and tree communities for each vegetation patch.

\begin{tabular}{lccc}
\hline & \multicolumn{3}{c}{ Subplot location } \\
\cline { 2 - 4 } & Bowal & Shrubland & Woodland \\
\hline Species richness (no. species $100 \mathrm{~m}^{-2}$ ) & & & \\
Regression equation & $6.34 \mathrm{x}-0.79$ & $3.09 \mathrm{x}+8.30$ & $1.53 \mathrm{x}+10.9$ \\
$\mathrm{R}^{2}$ & $52.50 \%$ & $26.50 \%$ & $3.00 \%$ \\
ANOVA, $\mathrm{P}$ & 0.018 & 0.128 & 0.630 \\
Density (stems $100 \mathrm{~m}^{-2}$ ) & & & \\
Regression equation & $5.78 \mathrm{x}^{\prime}+14.7$ & $2.40 \mathrm{x}^{\prime}+52.5$ & $7.51 \mathrm{x}^{\prime}+42.4$ \\
$\mathrm{R}^{2}$ & $42.20 \%$ & $16.20 \%$ & $55.80 \%$ \\
ANOVA, $\mathrm{P}$ & 0.042 & 0.249 & 0.013 \\
\hline
\end{tabular}

Regression equation corresponded to species richness (or stem density) $=\mathrm{a} \mathrm{x}$ (with $\mathrm{x}=$ species number $100 \mathrm{~m}^{-2}$ or $\mathrm{x}=$ stem density $\left(\right.$ stems $\left.\cdot 100 \mathrm{~m}^{-2}\right)+\mathrm{b}$; P: probability. 
Table 3. Ratio of woody undergrowth over tree densities (stems $100 \mathrm{~m}^{-2}$ ) for the most 15 shared species in the study vegetation patches.

\begin{tabular}{|c|c|c|c|c|c|c|c|c|c|}
\hline \multirow{2}{*}{ Species name } & \multicolumn{3}{|c|}{ Bowal } & \multicolumn{3}{|c|}{ Shrubland } & \multicolumn{3}{|c|}{ Woodland } \\
\hline & Undergrowth & Tree & Ratio & undergrowth & Tree & Ratio & Undergrowth & Tree & Ratio \\
\hline Annona senegalensis & 0.40 & 0.02 & 20.00 & 1.44 & 0.06 & 24.00 & 2.16 & 0.08 & 27.00 \\
\hline Burkea africana & 0.72 & 0.03 & 24.00 & 1.20 & 0.37 & 3.24 & 0.48 & 0.07 & 6.86 \\
\hline Cassia sieberiana & 0.88 & 0.44 & 2.00 & 0.48 & 0.02 & 24.00 & 0.08 & 0.01 & 8.00 \\
\hline Combretum nigricans & 0.08 & 0.03 & 2.67 & 0.24 & 0.16 & 1.50 & 0.48 & 0.08 & 6.00 \\
\hline Daniellia oliveri & 0.08 & 0.03 & 2.67 & 0.56 & 0.15 & 3.73 & 0.56 & 0.53 & 1.06 \\
\hline Detarium microcarpum & 10.08 & 1.1 & 9.16 & 1.36 & 0.30 & 4.53 & 0.80 & 0.01 & 80.00 \\
\hline Dichrostachys cinerea & 0.40 & - & - & 10.56 & - & - & 28.48 & 0.01 & 2848 \\
\hline Diospyros mespiliformis & 1.52 & 0.04 & 38.00 & 0.16 & 0.01 & 16.00 & 0.72 & 0.09 & 8.00 \\
\hline Flueggea virosa & 0.48 & - & - & 1.52 & - & - & 1.12 & - & - \\
\hline Gardenia ternifolia & 0.64 & - & - & 1.20 & - & - & 2.08 & - & - \\
\hline Guiera senegalensis & 4.72 & 0.11 & 42.91 & 12.48 & 0.05 & 249.60 & 17.44 & 0.03 & 581.33 \\
\hline Holarrhena floribunda & 0.80 & - & - & 0.08 & - & - & 0.72 & - & - \\
\hline Pteleopsis suberosa & 0.72 & - & - & 3.12 & 0.49 & 6.37 & 2.08 & 0.04 & 52.00 \\
\hline Terminalia macroptera & 0.64 & 0.22 & 2.91 & 4.00 & 0.39 & 10.26 & 2.64 & 0.19 & 13.89 \\
\hline Vitellaria paradoxa & 0.72 & 0.08 & 9.00 & 5.76 & 0.9 & 6.40 & 4.40 & 0.96 & 4.58 \\
\hline
\end{tabular}

and density of woody tree. Among the shared undergrowth species (Table 3), $G$. senegalensis and $D$. mespiliformis had high undergrowth density compared with their corresponding trees in bowal while $D$. cinerea and $G$. senegalensis had relatively abundant undergrowth over tree ratio in shrubland and woodland. From the overall 15 shared undergrowth species, Flueggea virosa (Roxb. ex Willd.) Voigt, Gardenia ternifolia Schumach. \& Thonn. and Holarrhena floribunda T. Durand \& Schinz did not exist as tree in the study areas.

\section{Discussion}

The present research analyzed the characteristics of woody undergrowth community in natural vegetation patches as habitats or regeneration niche in a state forest. Our results revealed that the type of vegetation or habitats importantly affects woody undergrowth community through establishment and recruitment. In accordance with our first specific objective, woody undergrowth associated with woodland sheltered higher number of species corresponding to $73.08 \%$ of the total counted species versus bowal with $48.08 \%$ (the lowest rate) and shrubland $69.23 \%$ (intermediate rate). At the scale of occupied surface, the species density (species. $100 \mathrm{~m}^{-2}$ ) of undergrowth community was lower in bowal but it was similar between both shrubland and woodland. Ecological undergrowth species were also represented and but differed between the three types of vegeta- 
tion. The species of Caesalpiniaceae (Burkea sp) and Mimosaceae (Acacia sp) families were the most abundant and frequent in each of the vegetation patches. Species richness observed in study areas may indicate that of viable seeds and propagules (mainly seed stock) that were stored on the floor or underground relatively to their dispersal system and have emerged during the favourable conditions of humidity and temperature. Nonetheless this significant difference may certainly result from the chance of species undergrowth to abundantly establish, grow and co-exist during their early stage [36] and hereafter influence the species diversity as response to heterogeneous areas described in community plant material (see Section 2.2). Current results on species richness are consistent with previous studies carried out in different climate zones [37] [38] [39] [40] [41]. By using a theoretical model during their investigation, [37] have demonstrated a positive effect of canopy composition (adult tree composition) on the undercanopy composition and shrub diversity through the modification of the soil conditions in where they grow. Therefore, in function of their ecological adaptive strategy, a many species may persist under particular canopy conditions as bowal (plenty opened), shrubland (light opened) and woodland (full cover) as area specific-species because vegetation patch likely act as filter or refuge for them to the detriment of area sensitive species [42]. This is the case of shared undergrowth species that can abundantly colonize and grow simultaneously in these three vegetation patches but their persistence is driven by their plasticity profile.

Regarding the second specific objective, species diversity in each vegetation patch was the consequence of capability to occur on bowal, shrubland and woodland leading to the co-existence of few species richness and abundant with uneven stem density even if the observed difference in the value of Simpson's diversity index for shrubland and woodland was insignificant. In shrubland, the most common families were Caesalpiniaceae, Combretaceae and Mimosaceae and highly contributed to increase the species diversity of undergrowth reservoir through the species number representing each of them in study sites during sampling period (see Appendix). Although the community associated with bowal sheltered lower species richness and diversity relating to shrubland, its diversity was similar with that of woodland undergrowth community as the proven of preference regeneration niche for each species. Current observations corroborate that obtained by [42] [43]. By comparing plant diversity between bowé (plural of bowal) and adjacent woodlands, these authors have pointed out lower woody species occurring on bowé with the predominance of $A$. macrostachya, $C$. glutinosum, C. nigricans, D. microcarpum and L. microcarpa individuals as resistant species to drought and with high regeneration potentials whereas $\mathrm{Fa}$ baceae family was well represented along the Njoro and Kamweti rivers by Acacia sp [44]. Therefore the low species diversity of woody undergrowth on bowal may result from the stressful soil conditions (edaphic factors), such as incrusted soil surface, absence of litter (bare soil) leading to water deficiency. Such in- 
crusted soil certainly reduce significantly space available for tree species to establish or prevent undergrowth to take root.

While vegetation patches significantly differ in species diversity, the overall abundance of undergrowth individuals evolved across sites and so did collar diameter and height class distribution. Our results showed that the density of undergrowth was significantly lower on bowal only in where the density value was twice that observed in shrubland and woodland (see Table 1). Such a reduced stem density of undergrowth community on bowal may depict limit in undergrowth establishment with scattered individuals [43] while shrubland and woodland together appeared with aggregated individuals as positive effect of canopy extend for undergrowth establishment contrary to [45]. Another explanation of unbalanced distribution in the different habitats may be that some species better fit a given environment than others at both undergrowth and adult tree stages. The co-existence of undergrowth individuals of the same and different species in each community is linked to the type of growing niche and their relationships with the existing ecological factors.

Besides, density distribution, undergrowth community on both bowal and shrubland had larger stump trunk in view of the collar diameter value. These communities constitute similar homogeneous group for stem collar diameter but differed from woodland. One may question whether the size of stem (big strunk) respond to an edaphic heterogeneity or to particular stress (competition with established species) in place or ontogenic factor? This is because high densities of undergrowth are likely to be correlated with small undergrowth sizes on each area. The higher collar diameter found on bowal mainly give an insight on the fact that woody undergrowth develop priority their underground systems as environment-feedback for a good anchoring, storing much nutrients and water to face unfavourable conditions for survival. Report indicated that undergrowth with larger stem diameter tend to survive better than small stem diameter and, are strong competitors [46]. Interestingly, most undergrowth individuals were under $100 \mathrm{~cm}$ tall and the proportion of those in the upper height class decreased on bowal (bell-shaped or gauss distribution). This fact may indicate that the high densities of undergrowth are likely to be correlated with small undergrowth sizes on each area. As for the distribution of undergrowth observed in shrubland and woodland, we can state that woody species roughly emerged jointly from propagules and/or soil seed stock (germination by seed) as response to favourable conditions (study period) and only the most successful species may be recruited in taller groups. This variation may also result from higher mortality rate or a slow growth that individuals experience along their life cycle and hereafter inducing a decreased density in taller groups (e.g. density in shrubland) corresponding to an instable communities and extreme vulnerability at early stage. Broadly, the three vegetation patches have a poor recruitment status regarding a gauss type structure observed, although some species abundantly established successfully in detail contributing to increase stem density. This is a case of D. cinerea, D. microcarpum in scrubland and woodland, and D. mespiliformis in bowal. Similar 
result was reported for Boswellia papyrifera population by [47] in Ethiopia where species exhibited a poor regeneration status.

Globally, the recruitment of woody species open to criticism because of the preponderance of undergrowth as regards adult trees through shared species as undergrowth $>$ trees. Nevertheless the variation of undergrowth species and stem density was significantly related to adult tree on bowal solely whereas $55.80 \%$ variations in woodland resulted from adult stem density only as the regression analysis results. This strong relationship suggest that woody undergrowth species successfully regenerated abundantly beneath adult trees but decline during undergrowth to tree transition in both bowal and woodland. Establishment pattern was likely promoted by the way adult tree may act on habitat conditions as facilitator or inhibitor during growth process.

\section{Conclusion}

Our results showed that undergrowth reservoirs varied across vegetation patches as response to the degree of heterogeneity in the study sites. In the Dinderesso state forest. These undergrowth reservoirs and may be an indicator of the species richness of soil propagules and/or seed stock. The three vegetation patches ranged into two homogeneous groups as the undergrowth community linked to bowal and that of shrubland-woodland. A particular undergrowth vegetation set is growing in bowal as area specific-species and stem density which positively vary in function of the associated tree community characters. Bowal as well as shrubland and woodland acts as suitable regeneration niche with reservoir for limited number of species that favourably co-exist. We may state that the co-existence of undergrowth of the same and different woody species and afterwards tree individuals in a particular community is in function of woody species themselves (intrinsic factors as biotic), habitat-specific biotic (protection from stand canopy) and the type of growing niche and their different interrelated mechanisms. Nonetheless, the main driver of observed distinction is the edaphic factors at small spatial scale (bowal) but undergrowth reservoir remain connected with family existing in its surroundings. Furthermore, this reservoir constitutes an indicator of species richness and abundance and hereafter a predictor of the physiognomy of woody tree community in place. The woody undergrowth community should be considered in the program of diversity management and degraded land restoration or other area similar to bowal. Based on the results of this study, field works could be undertaken to understand the characteristics of seed bank for bowal, shrubland and woodland regarding the undergrowth and tree communities and various conditions as the infiltration of soil water and biotic factor effects.

\section{Acknowledgements}

Current study did not obtain any external financial support. Authors would like to thank the staff of "Direction provincial des Eaux et Forêts, Houet" for author- 
izing us to work and ensuring our security in Dindéresso forest. Authors are grateful to the staff of IRD-Bobo for allowing us to access the institute e-library and to the anonymous reviewers for their valuables comments and suggestions.

\section{Data Availability Statement}

All data supporting the results of this study are available from the corresponding author (Traoré Saran) on decent demand.

\section{Conflicts of Interest}

The authors declare no conflicts of interest regarding the publication of this paper.

\section{References}

[1] Wilson, J.B., Peet, R.K., Dengler, J. and Pärtel, M. (2012) Plant Species Richness: The World Records. Journal of Vegetation Sciences, 23, 796-802. https://doi.org/10.1111/j.1654-1103.2012.01400.x

[2] Wanner, A., Suchrow, S., Kiehl, K., Meyer, W., Pohlmann, N., Stock, M. and Jensen, K. (2014) Scale Matters: Impact of Management Regime on Plant Species Richness and Vegetation Type Diversity in Wadden Sea Salt Marshes. Agriculture, Ecosystems and Environment, 182, 69-79. https://doi.org/10.1016/j.agee.2013.08.014

[3] Ky-Dembele, C., Tigabu, M., Bayala, J., Ouédraogo, S. J. and Odén, P.C. (2007) The Relative Importance of Different Regeneration Mechanisms in a Selectively Cut Savanna-Woodland in Burkina Faso, West Africa. Forest Ecology and Management, 243, 28-38. https://doi.org/10.1016/j.foreco.2007.01.091

[4] Zida, D., Tigabu, M., Sawadogo, L., Tiveau, D. and Odén, P.C. (2009) Long-Term Effects of Prescribed Early Fire, Grazing and Selective Tree Cutting on Seedling Populations in the Sudanian Savanna of Burkina Faso. African Journal of Ecology, 47, 97-108. https://doi.org/10.1111/j.1365-2028.2008.01011.x

[5] Adjahossou, S.G.C., Gouwakinnou, G.N., Houehanou, D.T., Sode, A.I., Yaoitcha, A.S., Houinato, M. and Sinsin, B. (2017) Efficacité des aires protégées dans la conservation d'habitats favorables prioritaires de ligneux de valeur au Bénin. Bois \& Forêts des Tropiques, 328, 67-76. https://doi.org/10.19182/bft2016.328.a31303

[6] Western, D., Mose, V.N., Maitumo, D. and Mburu, C. (2021) Long-Term Changes in the Plant Ecology of an African Savanna Landscape and the Implications for Ecosystem Theory and Conservation Management. Ecological Processes, 10, Article No. 15. https://doi.org/10.1186/s13717-021-00286-5

[7] Grubb, P.J. (1977) The Maintenance of Species-Richness in Plant Communities: The Importance of the Regeneration Niche. Biological Reviews, 52, 107-145. https://doi.org/10.1111/j.1469-185X.1977.tb01347.x

[8] Gignoux, J., Clobert, J. and Menaut, J.C. (1997) Alternative Fire Resistance Strategies in Savanna Trees. Oecologia, 110, 576-583. https://doi.org/10.1007/s004420050198

[9] Bellefontaine, R. (2005) Pour de nombreux ligneux, la reproduction sexuée n'est pas la seule voie: analyse de 875 cas-Texte introductif, tableau et bibliographie. Secheresse, 1E, 315-317.

[10] Traoré, S., Tigabu, M., Ouédraogo, S.J. Boussim, J.I., Guinko, S. and Lepage, M. (2008) Macrotermes Mounds as Sites for Tree Regeneration in a Sudanian Woodland 
(Burkina Faso). Plant Ecology, 198, 285-295.

https://doi.org/10.1007/s11258-008-9404-3

[11] Barton, D.N., Benjamin, T., Cerdán, C.R., DeClerck, F., Madsen, A.L., Rusch, G.M., Salazar, Á.G., Sanchez, D., and Villanueva, C. (2016) Assessing Ecosystem Services from Multifunctional Trees in Pastures Using Bayesian Belief Networks. Ecosystem Services, 18, 165-174. https://doi.org/10.1016/j.ecoser.2016.03.002

[12] Do, T.V., Cam, N.V., Sato, T, Binh, N.T., Kozan, O, Thang, N.T. and Mitlöhner, R. (2016) Post-Logging Regeneration and Growth of Commercially Valuable Tree Species in Evergreen Broadleaf Forest, Vietnam. Journal of Tropical Forest Science, 28, 426-435. https://www.jstor.org/stable/43956809

[13] Fern, K., Fern, A. and Morris, R. (2016) Useful Tropical Plants Database 2014. http://tropical.theferns.info/

[14] Achille, L., Zhang, K., Eloge, K., Kouassi, C. and Michel, M. (2021) Influence of Spatial Distribution on the Regeneration of Piptadeniastrum africanum and Ocotea usambaernsis in Kalikuku, Lubero, North Kivu, Democratic Republic of Congo. Open Journal of Ecology, 11, 527-539. https://doi.org/10.4236/oje.2021.117034

[15] Attua, E.M., Awanyo, L. and Antwi, E.K. (2017) Effects of Anthropogenic Disturbance on Tree Population Structure and Diversity of a Rain Forest Biosphere Reserve in Ghana, West Africa. African Journal of Ecology, 56, 116-127. https://doi.org/10.1111/aje.12427

[16] Sebata, A. (2017) Chapter 3. Ecology of Woody Plants in African Savanna Ecosystems. In: Yousaf, Z., Ed., Plant Ecology - Traditional Approaches to Recent Trends, IntechOpen, London, 25-42. https://doi.org/10.5772/intechopen.69865

[17] Sane, B., Coly, I., Badji, A., Diatta, T., Goudiaby, A. and Ngom, D. (2021) Characteristics of the Flora and Woody Vegetation of Agroforestry Parks in the District of Kataba 1 (Bignona, Lower Casamance). Open Journal of Ecology, 11, 741-757. https://doi.org/10.4236/oje.2021.1111046

[18] Liu, Q., Bi, L.Z., Song, G.H., Wang, Q.B. and Jin, G.Z. (2018) Species-Habitat Associations in an Old-Growth Temperate Forest in Northeastern China. BMC Ecology, 18, Article No. 20. https://doi.org/10.1186/s12898-018-0177-9

[19] Ræbild, A., Hansen, U.B. and Kambou, S. (2011) Regeneration of Vitellaria paradoxa and Parkia biglobosa in a Parkland in Southern Burkina Faso. Agroforest Systems, 85, 443-453. https://doi.org/10.1007/s10457-011-9397-0

[20] Gignoux, J., Konaté, S., Lahoreau, G., Roux, X. and Simioni, G. (2016) Allocation Strategies of Savanna and Forest Tree Seedlings in Response to Fire and Shading: Outcomes of a Field Experiment. Scientific Reports, 6, Article No. 38838. https://doi.org/10.1038/srep38838

[21] Alem, S. and Pavlis, J. (2012) Native Woody Plants Diversity and Density under Eucalyptus camaldulensis Plantation, in Gibie Valley, South Western Ethiopia. Open Journal of Forestry, 2, 232-239. https://doi.org/10.4236/ojf.2012.24029

[22] Paré, S., Savadogo, P., Tigabu, M., Oden, P.C and Ouadba, J.M. (2009) Regeneration and Spatial Distribution of Seedling Populations in Sudanian Dry Forests in Relation to Conservation Status and Human Pressure. Tropical Ecology, 50, 339-353.

[23] Driessen, P., Deckers, J. and Spaargaren, O. (2001) Lecture Notes on the Major Soils of the World. Food and Agriculture Organization of the United Nations, Rome.

[24] Doamba, S.W.M.F., Savadogo, P. and Nacro, H.B. (2014) Rôle des feux de savane sur les caractéristiques biogéochimiques des sols en zone soudanienne du Burkina Faso. International Journal of Biological and Chemical Sciences, 8, 777-793. https://doi.org/10.4314/ijbcs.v8i2.34 
[25] White, F. (1983) The Vegetation of Africa, a Descriptive Memoir to Accompany the UNESCO/AETFAT/UNSO Vegetation Map of Africa. UNESCO. Natural Resources Research.

[26] Fontès, J. and Guinko, S. (1995) Carte de la végétation et de l'occupation du sol du Burkina Faso/ Notice explicative. Laboratoire d'Ecologie Terrestre, Institut de la Carte Internationale de la Végétation. CNRS, Université de Toulouse III (France)/ Institut du Développement Rural, Faculté des Sciences et Techniques, Université de Ouagadougou, Ouagadougou.

[27] Arbonnier, M. (2002) Arbres, arbustes et lianes des zones sèches de l'Afrique de l'Ouest. CIRAD, MNHN, UICN, Montpellier.

[28] Bellefontaine, R. (1997) Synthèse des espèces des domaines sahélien et soudanien qui se multiplient naturellement par voie végétative. In: d'Herbès, J.M., Ambouta, J.M.K. and Peltier, R., Eds., Fonctionnement et gestion des écosystèmes forestiers contractés sahéliens, John Libbey Eurotext, Paris, 95-104.

[29] Kéita, I. (2019) Impact des termitières épigées sur la dynamique et la régénération de la végétation ligneuse dans la forêt classée de Dinderesso, Burkina Faso. Master's Thesis, Department of Biological Sciences, Université Nazi Boni, Bobo-Dioulasso.

[30] Montgomery, R.A. and Chazdon, R.L. (2001) Forest Structure, Canopy Architecture, and Light Transmittance in Tropical Wet Forests. Ecology, 82, 2707-2718. https://doi.org/10.1890/0012-9658(2001)082[2707:FSCAAL]2.0.CO;2

[31] Traoré, S., Nombré, S.A.H., Keïta, I., Nacro, H.B. and Sinsin, B. (2022) Can Stand Density and Stem Stratification Be Indicators of Aboveground Biomass in Woody Plant Recruitment in Savannah. Open Journal of Forestry, 12, 41-59. https://doi.org/10.4236/ojf.2022.121003

[32] IUCN (2021) The IUCN Red List of Threatened Species. Version 2021-3. https://www.iucnredlist.org

[33] IPNI (2021) International Plant Names Index. The Royal Botanic Gardens, Kew, Harvard University Herbaria \& Libraries and Australian National Botanic Gardens. http://www.ipni.org

[34] Gotelli, N.J. and Colwell, R.K. (2011) Chapter 4. Estimating Species Richness. In: Magurran, A.E. and McGill, B.J., Eds., Biological Diversity: Frontiers in Measurement and Assessment, Oxford University Press, New York, 39-54.

[35] DeJong, T.M. (1975) A Comparison of Three Diversity Indices Based on Their Components of Richness and Evenness. Oikos, 26, 222-227. https://www.jstor.org/stable/3543712 https://doi.org/10.2307/3543712

[36] Traoré, S. and Jouquet, P. (2020) Growth Performance and Adaptive Strategy of Early Seedlings of Three Savanna Woody Species in Pots as Feedback to the Soil of Macrotermes subhyalinus Mound. European Scientific Journal, 16, 20 p. https://doi.org/10.19044/esj.2020.v16n3p1

[37] Yuan, Z., Gazol, A., Wang, X., Xing, D., Lin, F., Bai, X., Zhao, Y., Li, B. and Hao, Z. (2011) What Happens below the Canopy? Direct and Indirect Influences of the Dominant Species on Forest Vertical Layers. Oikos, 121, 1145-1153. https://doi.org/10.1111/j.1600-0706.2011.19757.x

[38] Amani, C., Vleminckx, J., de la Thibauderie, T.D., Lejoly, J., Meerts, P. and Hardy, O.J. (2013) Species Responses to Edaphic Heterogeneity in Semi-Deciduous Forests from the Congo Basin. Greener Journal of Biological Sciences, 3, 365-374. https://doi.org/10.15580/GJBS.2013.10.112913997

[39] Zhu, J., Lu, D. and Zhang, W. (2014) Effects of Gaps on Regeneration of Woody 
Plants: A Meta-Analysis. Journal of Forestry Research, 25, 501-510. https://doi.org/10.1007/s11676-014-0489-3

[40] Nakamura, A., Kitching, R.L., Cao, M., Creedy, T.J., Fayle, T.M., Freiberg, M., Hewitt, C.N., Itioka, T, Koh, L.P, Ma, K., Malhi, Y., Mitchell, A., Novotny, V., Ozanne, C.M.P., Song, L.A., Wang, H. and Ashton, L.A. (2017) Forests and Their Canopies: Achievements and Horizons in Canopy Science. Trends in Ecology \& Evolution, 32, 438-451. https://doi.org/10.1016/j.tree.2017.02.020

[41] Yadav, S. and Sharma, L. (2021) Distribution Pattern of Some Ethnomedicinal Plants of Mayali in Jashpur District. Applied Ecology and Environmental Sciences, 9, 950953. https://doi:10.12691/aees-9-11-6

[42] Larson, J.E. and Funk, J.L. (2016) Regeneration: An Overlooked Aspect of Trait-Based Plant Community Assembly Models. Journal of Ecology, 104, 1284-1298.

https://doi:10.1111/1365-2745.12613

[43] Zwarg, A., Schmidt, M., Janßen, T., Hahn, K. and Zizka, G. (2012) Plant Diversity, Functional Traits and Soil Conditions of Grass Savannas on Lateritic Crusts (Bowé) in South Eastern Burkina Faso. Flora et Vegetatio Sudano-Sambesica, 15, 15-24. https://doi.org/10.21248/fvss.15.18

[44] Koskey, J.C., M'Erimba, C.M. and Ogendi, G.M. (2021) Effects of Land Use on the Riparian Vegetation along the Njoro and Kamweti Rivers, Kenya. Open Journal of Ecology, 11, 807-827. https://doi.org/10.4236/oje.2021.1111049

[45] Padonou, E.A., Adomou, A.C., Bachmann, Y., Lykke, A.M. and Sinsin, B. (2014) Vegetation Characteristics of Bowé in Benin (West Africa). Journal of Plant Sciences, 2, 250-255. https://doi.org/10.11648/j.jps.20140205.27

[46] Morrissey, R.C, Jacobs, D.F., Davis, A.S., Rathfon, R.A. (2010) Survival and Competitiveness of Quercus rubra Regeneration Associated with Planting Stocktype and Harvest Opening Intensity. New Forests, 40, 273-287. https://doi.org/10.1007/s11056-010-9199-7

[47] Bantihun, A. and Tesema, T. (2018) Regeneration Status of Acacia polyacantha and Boswellia papyrifera Species in Shimelegir Forest, Jawi District, Ethiopia. Journal of Biodiversity and Endangered Species, 6, Article No. 8. 
Appendix. Complete List of Undergrowth Species and Stem Number (Density Stems•100 $\mathbf{m}^{-2}$ ) in 50 Subplots Laid in Each Vegetation Patch

\begin{tabular}{|c|c|c|c|c|c|c|c|}
\hline \multirow{2}{*}{ Species-name } & \multirow{2}{*}{ Family } & \multicolumn{3}{|c|}{ Number of undergrowth $(\mathrm{N})$} & \multicolumn{3}{|c|}{ Density (stems $\cdot 100 \mathrm{~m}^{2}$ ) } \\
\hline & & Bowal & Shrubland & Woodland & Bowal & Shrubland & Woodland \\
\hline Acacia dudgeoni Craib ex Hall. & Mimosaceae & - & - & 1 & - & - & 0.08 \\
\hline Acacia erythrocalyx Brenan & Mimosaceae & - & 9 & - & - & 0.72 & - \\
\hline Acacia macrostachya Reichenb. ex DC & Mimosaceae & 2 & - & - & 0.16 & - & - \\
\hline Annona senegalensis Pers. & Annonaceae & 5 & 18 & 27 & 0.4 & 1.44 & 2.16 \\
\hline Anogeissus leiocarpus (DC.) Guill. \& Perr. & Combretaceae & - & 1 & 37 & - & 0.08 & 2.96 \\
\hline Baissea multiflora A. DC. & Apocynaceae & - & - & 1 & - & - & 0.08 \\
\hline Brideliaferruginea Benth & Euphorbiaceae & - & 2 & - & - & 0.16 & - \\
\hline Bridelia micrantha (Hochst.) Baill. & Euphorbiaceae & - & 28 & 28 & - & 2.24 & 2.24 \\
\hline Burkea africana Hook. & Caesalpiniaceae & 9 & 15 & 6 & 0.72 & 1.2 & 0.48 \\
\hline Cassia arereh Delile & Caesalpiniaceae & - & 3 & 7 & - & 0.24 & 0.56 \\
\hline Cassia sieberiana DC. & Caesalpiniaceae & 11 & 6 & 1 & 0.88 & 0.48 & 0.08 \\
\hline Celtis integrifolia Lam. & Ulmaceae & 4 & - & 1 & 0.32 & - & 0.08 \\
\hline Combretum glutinosum Perr. ex DC. & Combretaceae & 23 & - & - & 1.84 & - & - \\
\hline Combretum micranthum G. Don & Combretaceae & 6 & - & - & 0.48 & - & - \\
\hline Combretum molle R. Br ex G. Don & Combretaceae & - & 6 & - & - & 0.48 & - \\
\hline Combretumnigricans Lepr. exGuill \& Perr. & Combretaceae & 1 & 3 & 6 & 0.08 & 0.24 & 0.48 \\
\hline Crossopteryx febrifuga Benth. & Rubiaceae & - & - & 2 & - & - & 0.16 \\
\hline Daniellia oliveri (Rolfe) Hutch. \& Dalz. & Caesalpiniaceae & 1 & 7 & 7 & 0.08 & 0.56 & 0.56 \\
\hline Detarium microcarpum Guill. \& Perr. & Caesalpiniaceae & 126 & 17 & 10 & 10.08 & 1.36 & 0.8 \\
\hline Dichrostachys cinerea (L.) Wight \& Arn. & Mimosaceae & 5 & 132 & 356 & 0.4 & 10.56 & 28.48 \\
\hline Diospyros mespiliformis Hochst. Ex A. DC & Ebenaceae & 19 & 2 & 9 & 1.52 & 0.16 & 0.72 \\
\hline Entada africana Guill. \& Perr. & Mimosaceae & 86 & - & 3 & 6.88 & - & 0.24 \\
\hline Flueggea virosa (Roxb. ex Willd.) Voigt & Euphorbiaceae & 6 & 19 & 14 & 0.48 & 1.52 & 1.12 \\
\hline Gardenia aqualla Stapf \& Hutch. & Rubiaceae & - & 11 & 2 & - & 0.88 & 0.16 \\
\hline Gardenia erubescens Stapf \& Hutch. & Rubiaceae & - & 8 & 6 & - & 0.64 & 0.48 \\
\hline Gardenia ternifolia Schumach. \& Thonn. & Rubiaceae & 8 & 15 & 26 & 0.64 & 1.2 & 2.08 \\
\hline Grewia bicolor Juss. & Tiliaceae & - & - & 4 & - & - & 0.32 \\
\hline Guiera senegalensis Lam. & Combretaceae & 59 & 156 & 218 & 4.72 & 12.48 & 17.44 \\
\hline Holarrhenafloribunda T. Durand \& Schinz & Apocynaceae & 10 & 1 & 9 & 0.8 & 0.08 & 0.72 \\
\hline Hymenocardia acida Tul. & Euphorbiaceae & - & - & 4 & - & - & 0.32 \\
\hline Isoberlinia doka Craib \& Stapf & Fabaceae & - & - & 1 & - & - & 0.08 \\
\hline Jatropha curcas L. & Euphorbiaceae & 2 & - & - & 0.16 & - & - \\
\hline
\end{tabular}




\section{Continued}

\begin{tabular}{|c|c|c|c|c|c|c|c|}
\hline Khaya senegalensis A. Juss. & Meliaceae, & - & 18 & 11 & - & 1.44 & 0.88 \\
\hline Lannea acida A. Rich., Guill. \& Perr. & Anacardiaceae & - & 1 & 2 & - & 0.08 & 0.16 \\
\hline Lannea velutina A. Rich., Guill. \& Perr. & Anacardiaceae & 6 & - & - & 0.48 & - & - \\
\hline Maranthes polyandra (Benth.) Prance & Chrysobalanaceae & - & 12 & - & 0 & 0.96 & - \\
\hline $\begin{array}{l}\text { Opilia celtidifolia (Guill. \& Perr.) Endl. } \\
\text { ex Walp. }\end{array}$ & Opiliaceae & 1 & 7 & - & 0.08 & 0.56 & - \\
\hline Parinari curatellifolia Planch. ex Benth. & Chrysobalanaceae & - & 2 & 4 & - & 0.16 & 0.32 \\
\hline $\begin{array}{l}\text { Piliostigma thonningii (Schumach.) } \\
\text { Milne Redh. }\end{array}$ & Caesalpiniaceae & - & 43 & 2 & - & 3.44 & 0.16 \\
\hline Prosopis africana Taub. & Fabaceae.- & - & 45 & 4 & - & 3.6 & 0.32 \\
\hline Pteleopsis suberosa Engl. \& Diels & Combretaceae & 9 & 39 & 26 & 0.72 & 3.12 & 2.08 \\
\hline Pterocarpus erinaceus Poir. & Fabaceae & - & 9 & 1 & - & 0.72 & 0.08 \\
\hline Saba senegalensis (A. DC.) Pichon & Apocynaceae & 20 & - & - & 1.6 & - & - \\
\hline Securidaca longepedunculata Fresen & Polygalaceae & - & 21 & - & - & 1.68 & - \\
\hline Strychnos spinosa Lam. & Loganiaceae & 5 & - & 1 & 0.4 & - & 0.08 \\
\hline Terminalia avicennioides Guill. \& Perr. & Combretaceae & - & 9 & 24 & - & 0.72 & 1.92 \\
\hline Terminalia laxiflora Engl. & Combretaceae & - & 24 & 11 & - & 1.92 & 0.88 \\
\hline Terminalia macroptera Guill. \& Perr. & Combretaceae & 8 & 50 & 33 & 0.64 & 4 & 2.64 \\
\hline Terminalia mollis M.A. Lawson & Combretaceae & - & 6 & - & - & 0.48 & - \\
\hline $\begin{array}{l}\text { Vitellaria paradoxa var. Paradoxa C. F. } \\
\text { Gaertn. }\end{array}$ & Sapotaceae & 9 & 72 & 55 & 0.72 & 5.76 & 4.4 \\
\hline Vitex doniana Sweet & Lamiaceae & - & - & 1 & - & - & 0.08 \\
\hline \multirow[t]{2}{*}{ Vitex simplicifolia Oliv. } & Lamiaceae & - & 5 & - & - & 0.4 & - \\
\hline & & 441 & 822 & 961 & 35.28 & 65.76 & 76.88 \\
\hline
\end{tabular}

